NBER WORKING PAPER SERIES

\title{
THE EXCESS CO-MOVEMENT OF COMMODITY PRICES
}

Robert S. Pindyck

Julio J. Rotemberg

Working Paper No. 2671

\author{
NATIONAL BUREAU OF ECONOMIC RESEARCH \\ 1050 Massachusetts Avenue \\ Cambridge, MA 02138 \\ July 1988
}

This work was supported by M.I.T.'s Center for Energy Policy Research, and by the National Science Foundation under Grant No. SES-8618502 to R. Pindyck and Grant No. SES-8619004 to J. Rotemberg. We want to thank Michael Boozer and Rebecca Emerson for their superb research assistance, and John Campbell, Thomas Stoker, and Kenneth West for helpful comments and suggestions. This research is part of NBER's research program in Financial Markets and Monetary Economics. Any opinions expressed are those of the authors not those of the National Bureau of Economic Research. 
NBER Working Paper \#2671

July 1988

THE FUESS CO-MOVEMENT OF COMMODITY PRICES

\section{ABSIRACT}

This paper tests and confirms the existence of a puzzling phenomenon the prices of largely unrelated raw commodities have a persistent tendency to move together. We show that this co-movement of prices is well in excess of anything that can be explained by the common effects of past, current, or expected future values of macroeconomic variables such as inflation, indus. trial production, interest rates, and exchange rates. These results are a rejection of the standard competitive model of commodity price formation with storage

Robert S. Pindyck Sloan School of Management Massachusetts Institute of Technology 50 Memorial Drive Cambridge, MA 02139
Julio J. Rotemberg Sloan School of Management Massachusetts Institute of Technology 50 Memorial Drive

Cambridge, MA 02139 


\section{Introduction.}

This paper tests and confirms the existence of a puzzling phenomenonthe prices of raw commodities have a persistent tendency to move together. We find that this co-movement of prices applies to a broad set of commodities that are largely unrelated, 1.e., for which the cross-price elasticities of demand and supply are close to zero. Furthermore, the comovement is well in excess of anything that can be explained by the common effects of inflation, or changes in aggregate demand, interest rates, and exchange rates.

Our test for excess co-movement is also a test of the standard competitive model of commodity price formation with storage. An innovative aspect of our test, and one that distinguishes it from, say, Eichenbaum's (1983, 1984) tests of finished goods inventory behavior under rational expectations, is that we do not need data on inventory stocks. Our test relies instead on the joint behavior of prices across a range of commodities, and the fact that those prices should only move together in response to common macroeconomic shocks.

This excess co-movement casts doubt on the standard competitive commodity price model. A possible explanation for it is that commodity price movements are to some extent the result of "herd" behavior in financial markets. (By "herd" behavior we mean that traders are alternatively bullish or bearish on all commodities for no plausible economic reason.) Indeed, our finding would be of little surprise to brokers, traders, and others who deal regularly in the futures and cash markets, many of whom have held the common belief that commodity prices tend to move together. Analyses of futures and commodity markets issued by brokerage firms, or that appear on the financial pages of newspapers and 


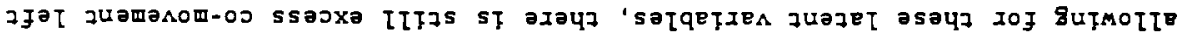

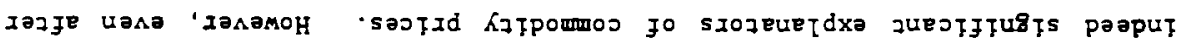

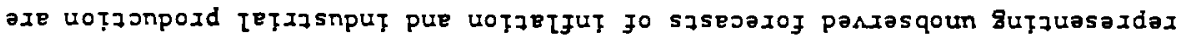

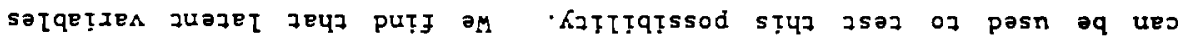

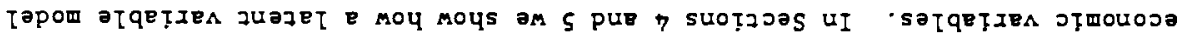

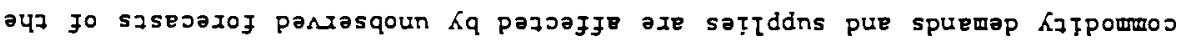

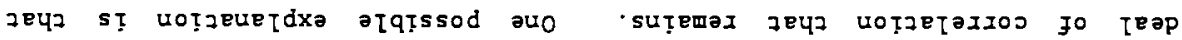

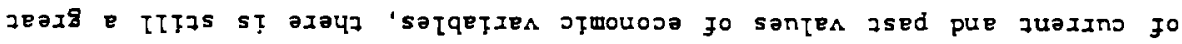

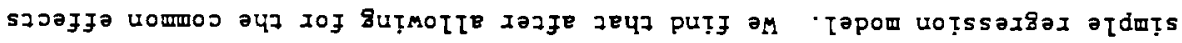

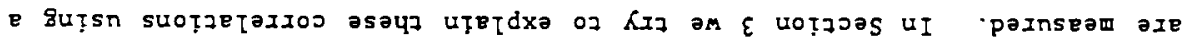

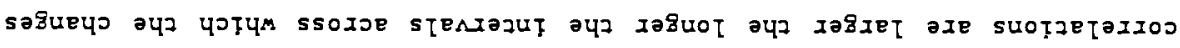

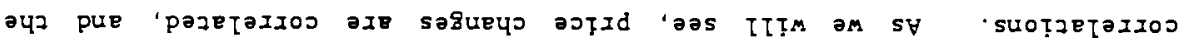

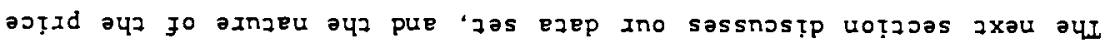

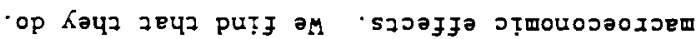

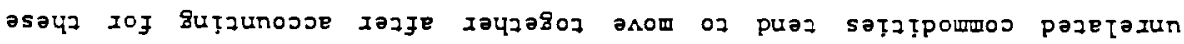

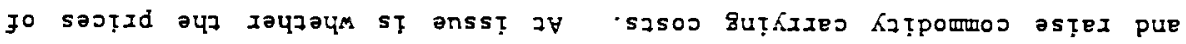

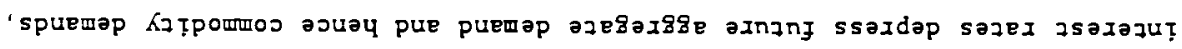

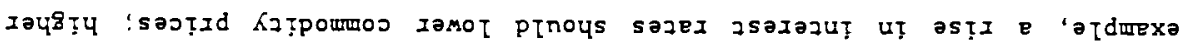

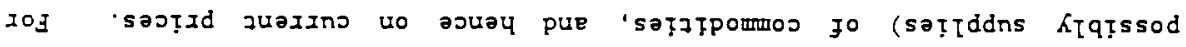

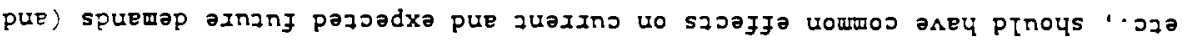

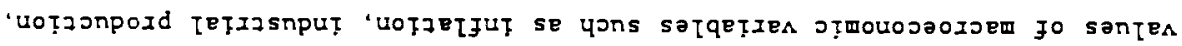

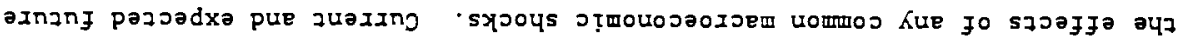

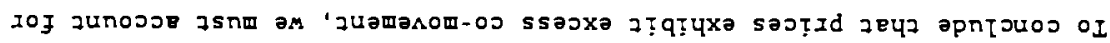

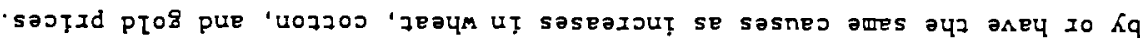

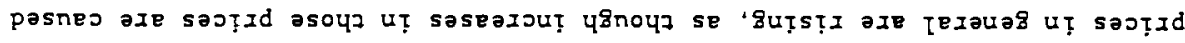

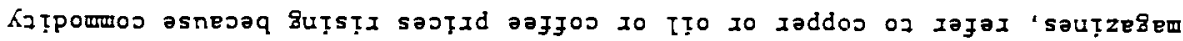


over. Section 6 concludes by discussing some limitations of our analysis and possible reasons for our findings.

\section{The Correlation of Commodicv Prices.}

We study monthly price changes for seven commodicies: whear, corton, copper, gold, crude oil, lumber, and cocoa. This is a broad spectrum of comodicies that are as unrelated as possible. For example, the agricultural products we have chosen are growi. in different climaces and have different uses. None of the comodities are substitutes or complements, none are co-produced, and none is used as a major input for the production of another. Barring price movements due to common macroeconomic factors, we would expect these prices to be uncorrelaced. 1

We use United States average monthly cash prices from 1960 through 1985. Ideally, these data should correspond to a current price quotation for immediace delivery of a homogeneous good. However, all comodities are at least somewhat heterogenous, and delivery daces can vary. We have tried to obtain price data that reflect as closely as possible what sellers are charging at the time for current delivery of a well-specified comodity. Specific price series and daca sources are listed in Appendix B.

Table 1 shows a correlation matrix for the monchly changes in the logarithms of these prices. Ten out of the 21 correlations exceed. 1 . Gold shows strong correlations with copper, crude oil, lumber, and cocoa; cotton is also correlated with copper, lumber, and wheat; and lumber is correlated with copper and cocoa.

Are these correlations as a group statistically significant? To answer this we can perform a likelihood ratio test of the hypothesis that the correlation matrix is equal to the identey matrix. It is worth discussing this test briefly because it is closely related to the cests we carry out in 


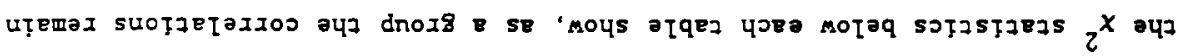

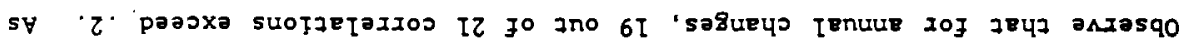

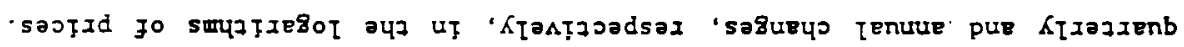

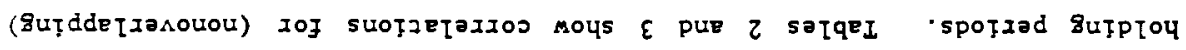

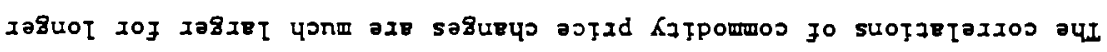

pazetajuosun ade sasjzd

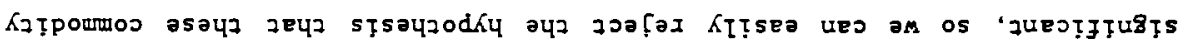

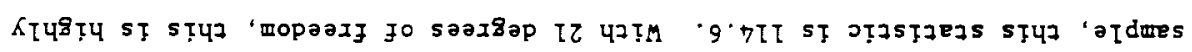

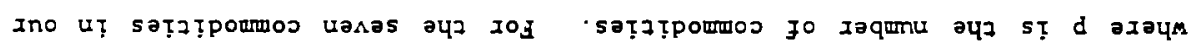

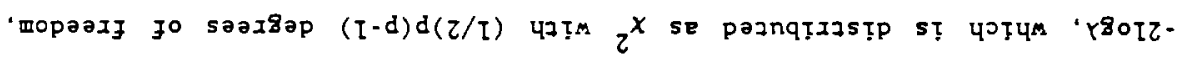

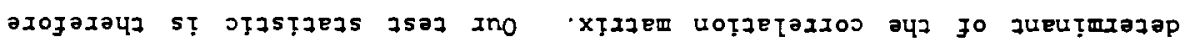

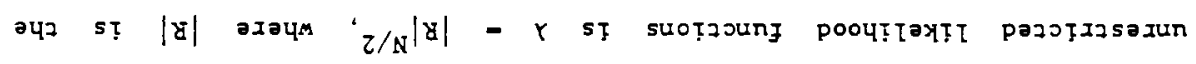

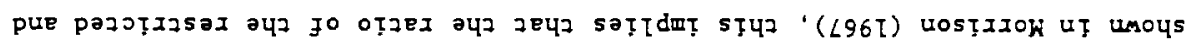

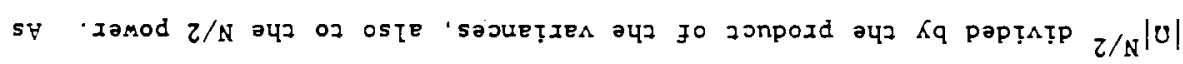

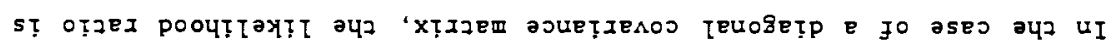

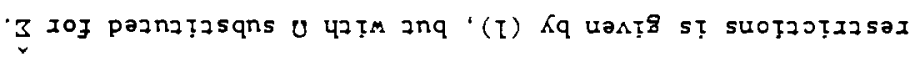

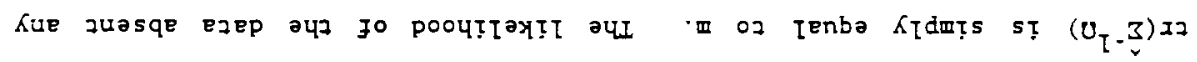

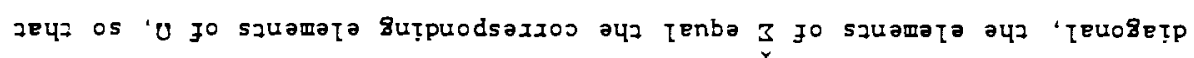

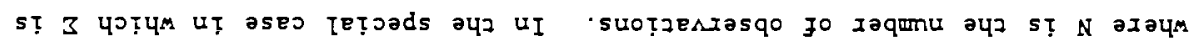

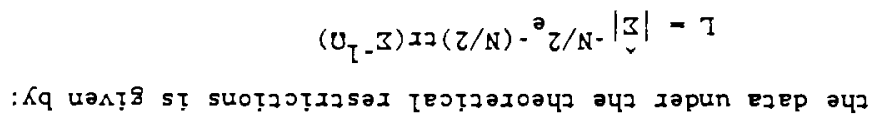

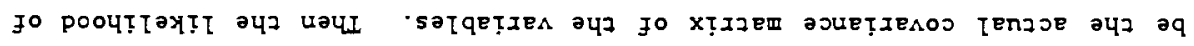

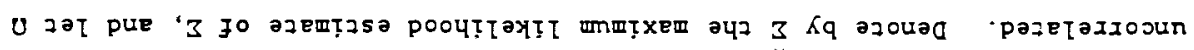

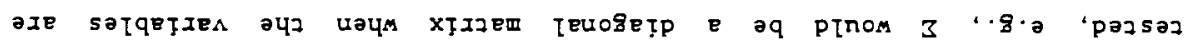

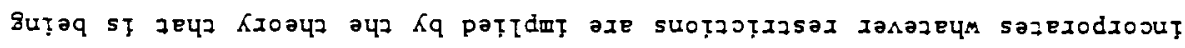

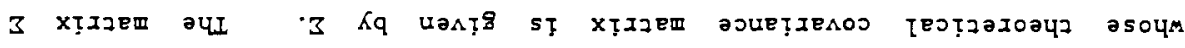

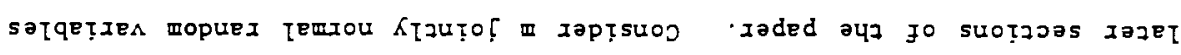


significant at the 1 percent level. Nonetheless, the significance level for the quarterly and annual changes are lower than for the monthly ones. This occurs because there are many fewer nonoverlapping yearly than monthly observations.

A better measure if the statistical significance of the quarterly and yearly correlations is obtained by using all of the available data, i.e., using overlapping observations. $\chi^{2}$ statistics computed as above using all overlapping observations give values of 194.9 for quarterly differences and 517.7 for annual differences. These statistics are not distributed as $x^{2}(21)$ because the use of overlapping data introduces serial dependence. We therefore computed, via Monte Carlo, 15,000 draws of our test statistics, $-2 \log \lambda$, under the null hypothesis that the monthly price changes are i.i.d. and uncorrelated across commodities. The highest volumes that we drew for these statistics were 221.3 for quarterly price changes, and 504.1 for yearly price changes. Thus these quarterly and annual correlations that we observe are highly significant.

Of course these correlations might be due to common macroeconomic factors, such as changes in current or expected future inflation or aggregate demand. In addition, macroeconomic variables may explain more of the price movements over longer horizons, which may account for the larger correlations that we find for longer holding periods. We explore these possibilities below.

3. The Explanatory Power of Current and Past Macroeconomic Variables.

Commodity prices may have common movements because of changes in macroeconomic variables that affect demands and/or supplies for broad sets of commodities. These changes can affect prices in two ways. First, macroeconomic variables may directly affect commodity demands and supplies. 


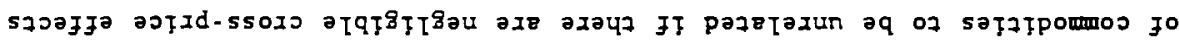

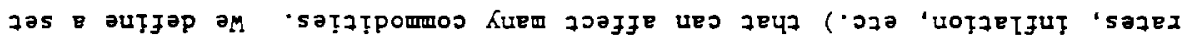

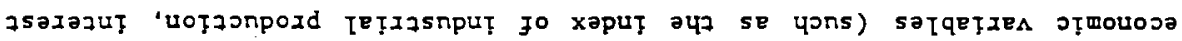

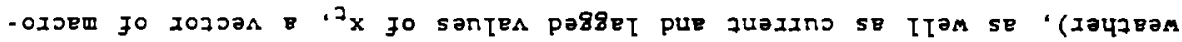

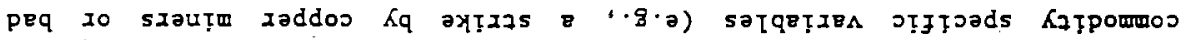

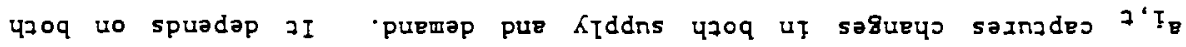

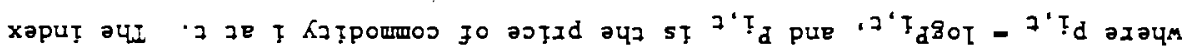

$$
\begin{aligned}
& 7^{\prime} T^{\top}{ }^{\top} q+7^{\prime} T_{B}-7^{\prime} I_{0}
\end{aligned}
$$

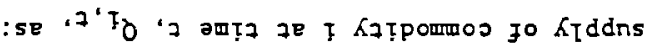

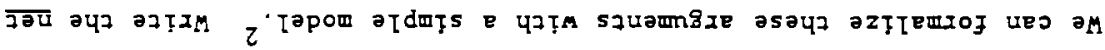
'saoțdd zuajuno 'uțege pue 'spuemap $\alpha_{3}$ țpommos

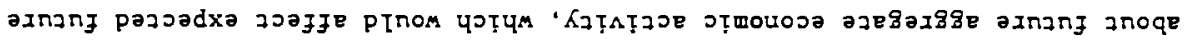

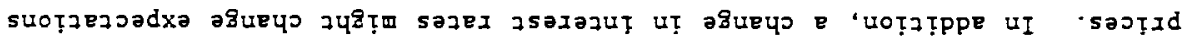

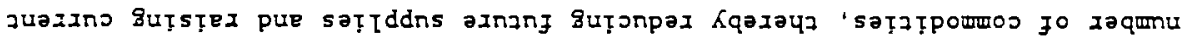

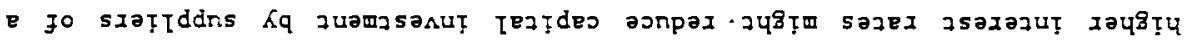

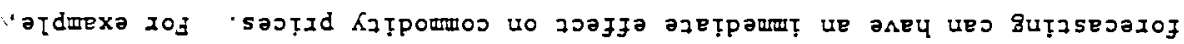

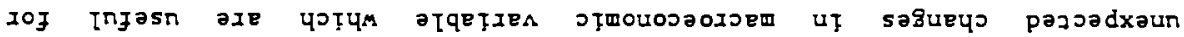

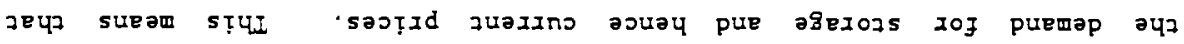

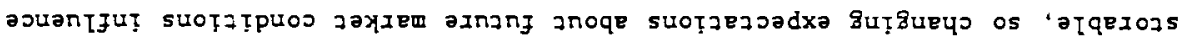

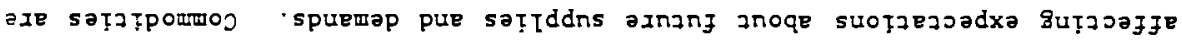

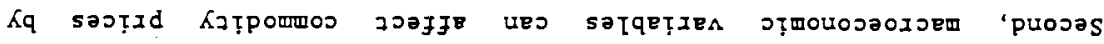

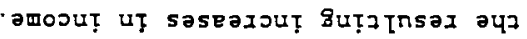

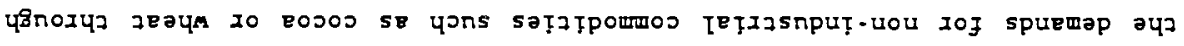

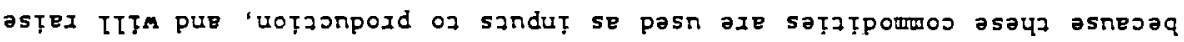

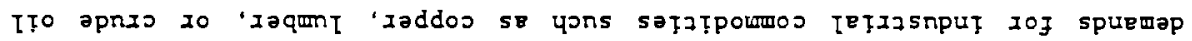

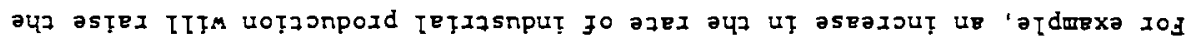


(so that $a_{1, t}$ does not Include the prices of other commodities), and if any commodity specific variable that affects $a_{1, t}$ does not affect $a_{j, t}, f+1$.

The evolution of inventory, $I_{i, t}$, is given by the accounting Identity:

$$
I_{i, t}=I_{i, t-1}+Q_{i, t}
$$

Finally, under the a sumption that risk-neutral inventory holders maximize expected profits, the evolution of the price of commodity $i$ is given by:

$$
r_{t}=\left[E_{t} P_{i, t+1}-C_{i, t}-P_{i, t}\right] / P_{i, t}
$$

where $r_{t}$ is the required rate of return, $E_{t}$ is the expectation conditional on all information available at time $t$, and $C_{i, t}$ is the one-period holding cost of the comodicy, less the capitalized flow of Its marginal convenience yield over the period.

The convenience yield is the flow of benefits that one obtains from holding stocks, e.g., the resulting assurance of supply as needed, ease of scheduling, etc. On the margin, this depends on the cotal quantity of inventory held; the larger is $I_{i, t}$, the smaller is the benefit from holding an extra unit of inventory. The convenience yield is also likely to depend on macroeconomic variables. ${ }^{3}$ For example, an increase in the rate of Industrial production implies an increase in the rate of consumption of Industrial commodities, and therefore an Increase in desired stocks. We model $c_{1, t}$, the logarithm of $C_{1, t}$, as a linear function of $I_{1, t}$ :

$$
c_{1, t}=n_{i, t}+r_{i} I_{i, t}
$$

where $n_{1, t}$ is a function of current and past values of $x_{t}$, the vector of macroeconomic variables.

Eqn. (4) says that prices at $t$ depend on expected future prices. Thus current prices depend on expected future condfions in the industry, and as we show in Appendix $A$, they are functions of current and expected future values of $x_{t}$. We assume that forecasts of $x_{t}$ are based on current and past 


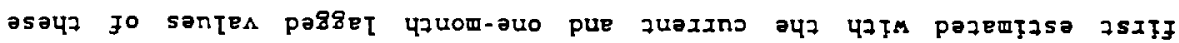
st I

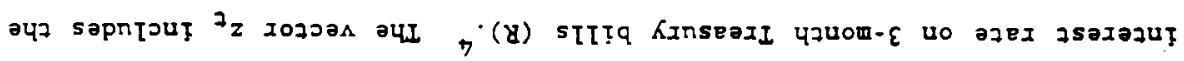

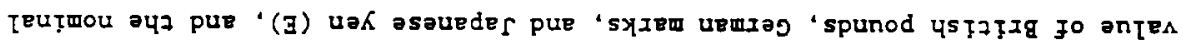

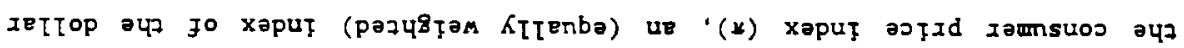

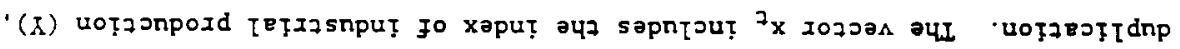

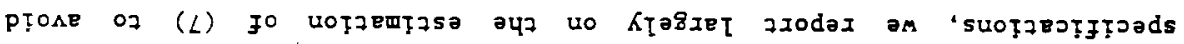

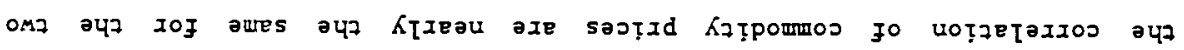

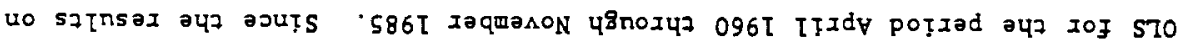

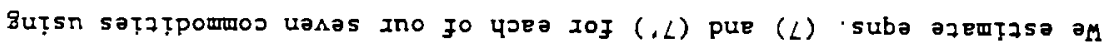

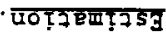

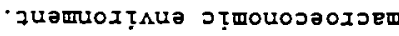

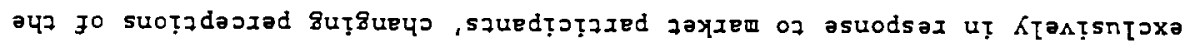

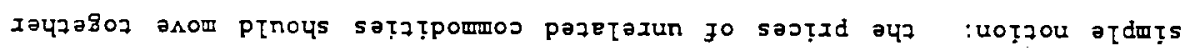

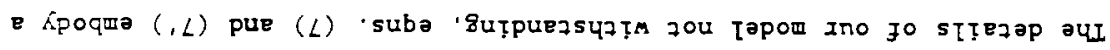

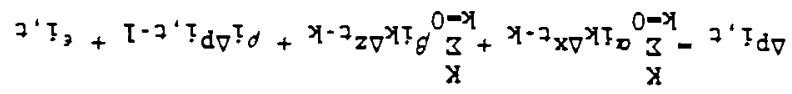

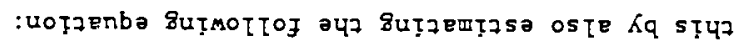

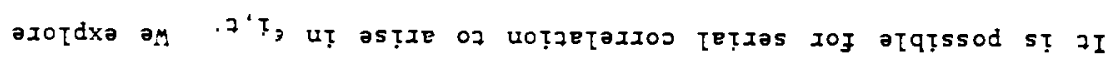

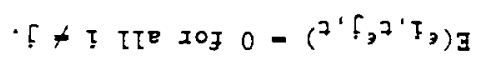

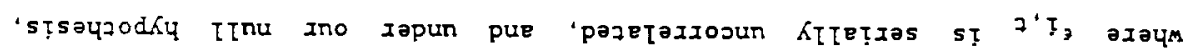

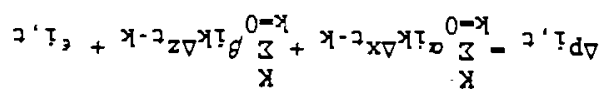

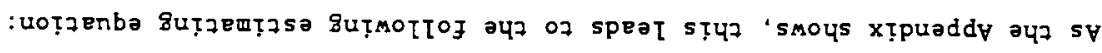

$$
\begin{aligned}
& { }^{7} z(\tau) \complement_{\phi}+7_{x(\tau)} \Gamma_{\theta}-\left\lceil+7 x^{2} z\right.
\end{aligned}
$$

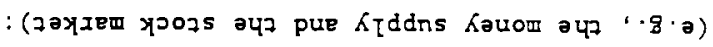

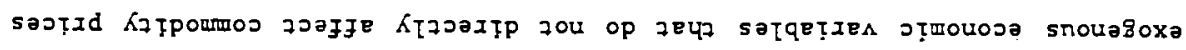

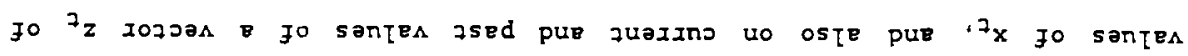


variables, and then is re-estimated with the current values and lags of one through six months.

Table 4 shows estimation resules for equations that include $x_{t}$ and $z_{t}$ current and lagged one month. Increases in inflation and the money supply are associated with in reases in the prices of all the commodities, and the interest rate with decreases. The effects of the other variables are more mixed, but as Table 5 shows, each variable has a statistically significant impact on commodity prices as a whole. That table presents likelihood ratio cests for group exclusions of explanatory variables from all seven commodity price equations. Column (1) applies to equations with one lag, and column (2) to equations with six lags. Each statistic is twice the difference of the log likelihood functions for the unrestricted and restricted models, and is distributed as $x^{2}$ with degrees of freedom equal to the number of restrictions ( 14 and 49 respectively). With the exception of stock returns in column (1) and industrial production in colum (2), these statistics are significant at the 1 percent level.

Denote by $\hat{\epsilon}_{t}$ the vector of residuals $\left(\hat{\epsilon}_{1}, t, \ldots, \hat{\epsilon}_{7}, t\right)^{\prime}$, and let $\mathrm{O}$ be the covariance matrix of $\hat{c}$. If our model is complete, $\Omega$ should be diagonal. We test whether $\Omega$ is indeed diagonal using the technique decribed in Section 2; the results are included in Table 5. The test statistic is significant at the 1 percent level for both versions of the model. The daca reject a diagonal covariance matrix more strongly when we include six lags of the explanatory variables. This might occur because in small samples the addition of irrelevant explanatory variables automatically reduces the variance of the $\hat{\epsilon}_{1}$ 's without necessarily reducing the covariances commensurately: 


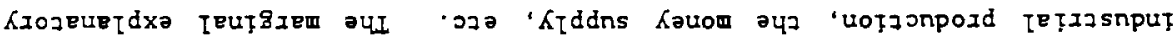

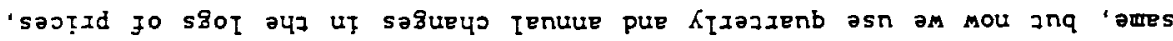

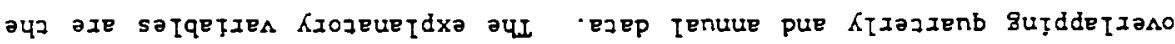
-uou Butsn (L) uba jo sajemtzsa lof $s, z$ ay smoys osie 9 a[qeI popntout aIE satqetzeA

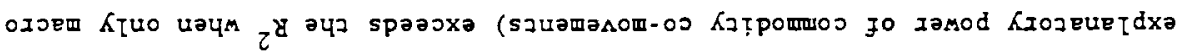

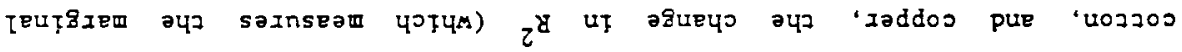

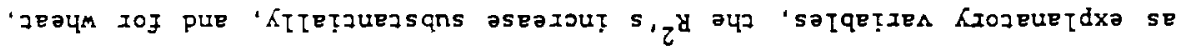

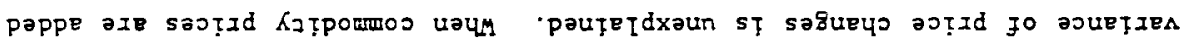

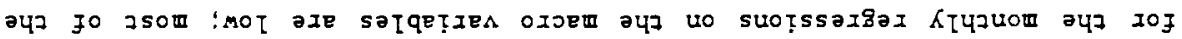

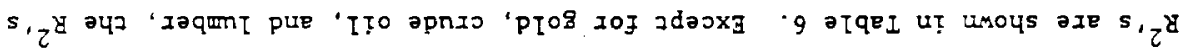

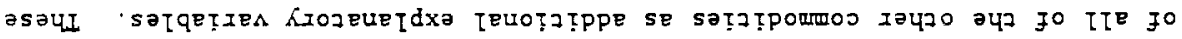

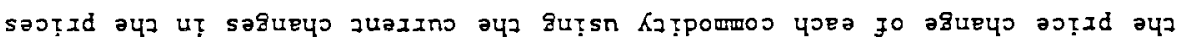

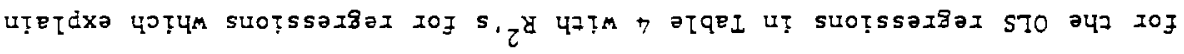

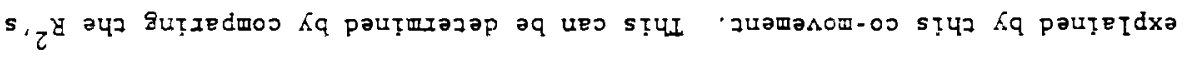

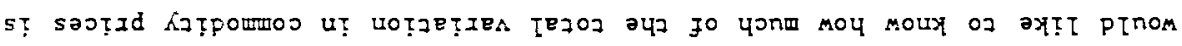

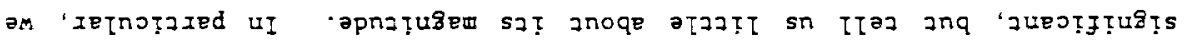

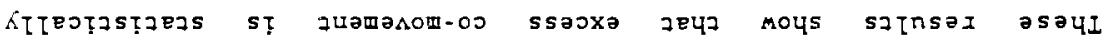

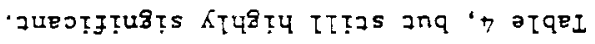

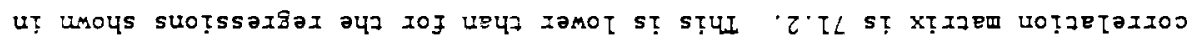

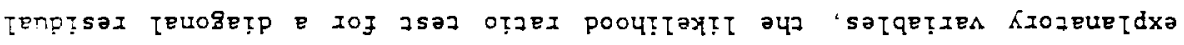

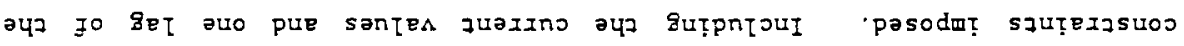

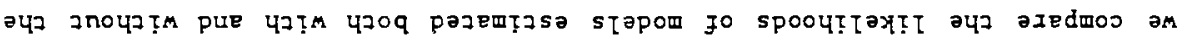

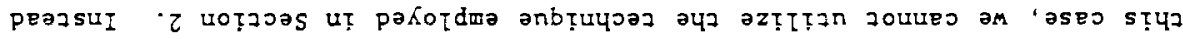

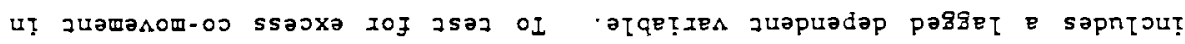

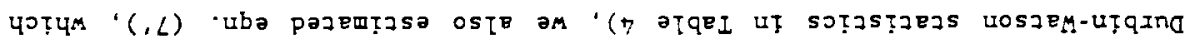

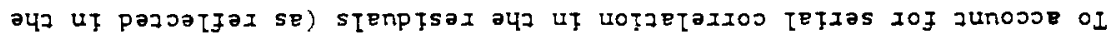


power of commodity price comovements tends to increase when we use quarterly and annual data. 5 In the case of cotton, for example, the addition of other commodity price changes as explanatory variables accounts for nearly half of the total variation in annual cotton price changes. Table 6 thus shows that comodity price co-movements explains a substantial fraction of the individual price movements.

We also examined the sensitivity of our results to the choice of sample period, using monthiy data and one lag of each explanatory variable. Leaving out the period October 1973 through December 1974 (during which commodity prices may have been broadly affected by OPEC, which may have also affected macroeconomic variables), the statistic for the absence of co-movements falls to 77.1. Extending the sample through October 1986 Iesults in a statistic of 75.4 , and shortening the sample so that it ends in November 1984 gives $83.0 .^{6}$ These statistics are all highly significant.

After accounting for comodity price movements that are due to common macroeconomic factors, price changes remain correlated across commodities. We make a further attempt to account for this the next two sections.

\section{A Latent Variable Model.}

In the previous section we tested whether correlations among commodicy prices can be atcributed to the correlation of each price with observable macroeconomic variables that are predictors of future conditions in commodity markets. This approach is subject to a serious limitation: Individuals have more information about future $x$ 's than can be obtained from any set of current and past $x^{\prime}$ s and $z$ 's which are directly observable. Thus eqn. (6) is too restrictive. Some of the news about future macroeconomic variables is of a qualitative nature which is difficult to include in the kinds of regressions reported above. This qualitative information could in 


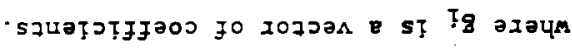

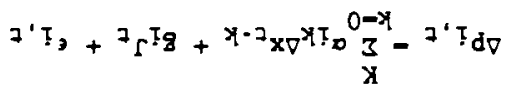

$$
\begin{aligned}
& \text { :se }(5, x \text { axnang }
\end{aligned}
$$

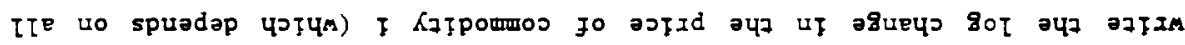

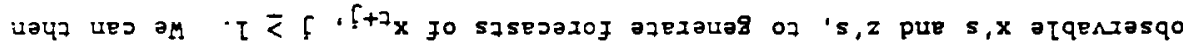

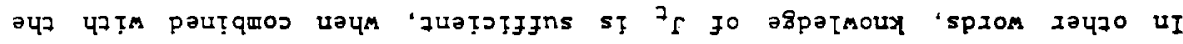

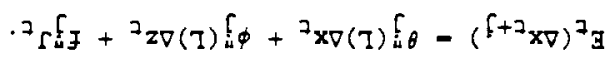

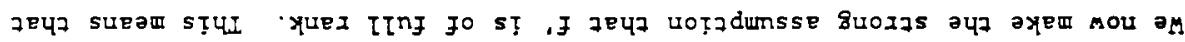

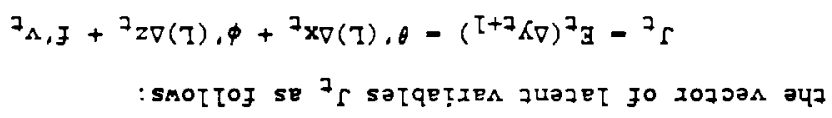

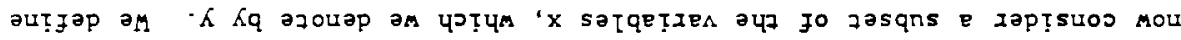

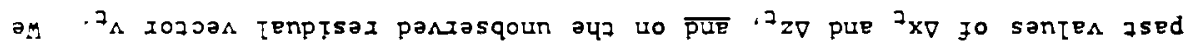

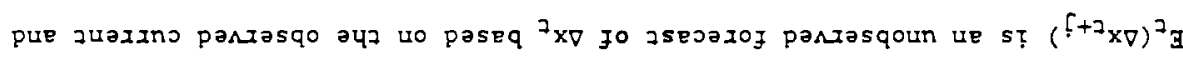

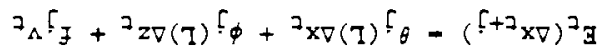

:(9) uba azTโexauas

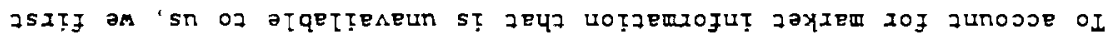
's,z Ino apntout sasneo ay snuI 's

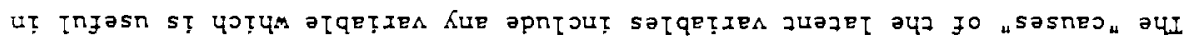

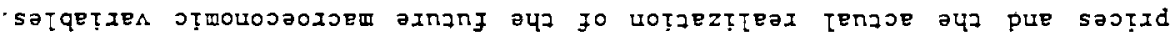

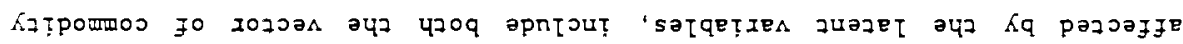

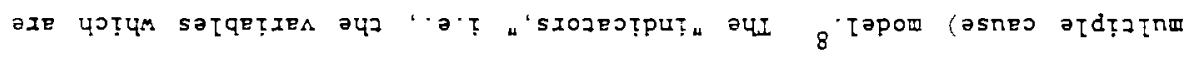

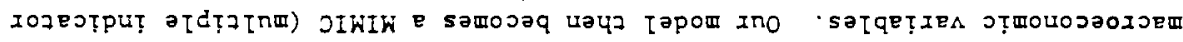

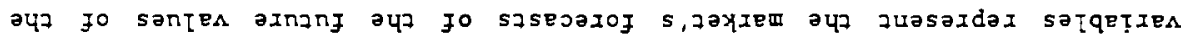

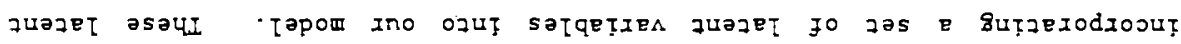

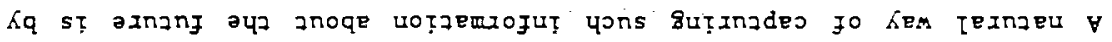
- sastid xţวy suome

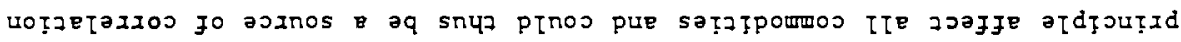


The latent variables we include are the expectation at $t$ of the value at $t+1$ of $y$. Therefore, the vector of residuals $w_{t}$ in the equation

$$
\Delta y_{t+1}=J_{t}+w_{t}
$$

is uncorrelated with any information avallable at $t$. The system we estimate then consists of (9), (11), and (12). The vector of latent variables $J$ has multi, fe causes, namely the $z^{\prime} s$, and multiple indicators, namely the curzent prices and future $y^{\prime} s$.

Our procedure is closely related to the more traditional instrumental variables method of estimating rational expectations models. Consistent estimates of $g_{i}$ could also be obtained by using the current and lagged $z$ 's as instruments for $\Delta y_{t+1}$ in a regression equation which is given by (11), where $J_{t}$ is replaced by $\Delta y_{t+1}$. As in the instrumental variables approach, we assume that certain variables (the $z^{\prime} s$ ) affect comodity prices only through their effect on agents' expectations of certain future variables.

Like our procedure, the instrumental variables approach gives consistent estimates of $g_{i}$, even when the instrument list is not exhaustive. However, the residuals from an instrumental variables regression cannot be used directly to test for excessive co-movement of commodicy prices. These residuals are constructed using the actual realized values of future macroeconomic variables. Since the market forecast must by necessity differ from these realized values, the residuals in all the equations will tend to be correlated.

We estimate (9), (11) and (12) by maximum likelihood, under the maintained assumption that the v's. W's and $c^{\prime} s$ are normally distributed. The contemporaneous variance-covariance matrix for the $v^{\prime} s$ as well as that for the w's is left unrestricted. We assume that v's are uncorrelated with ' 's and w's at all leads and lags, and that the same is true for the 
$\rightarrow$ จ IqEI jo

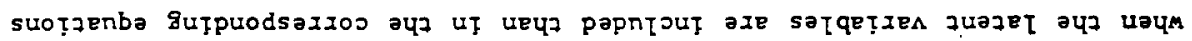

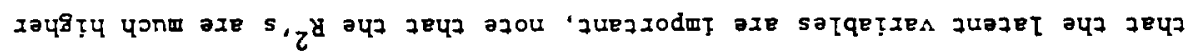

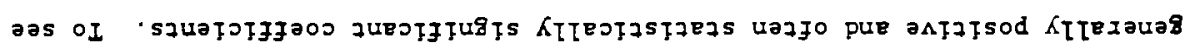

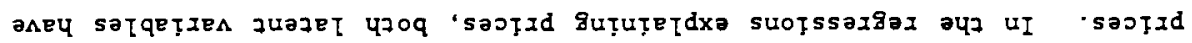

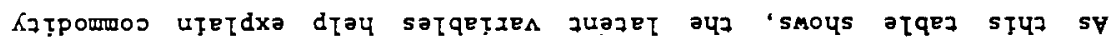

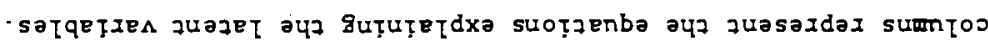

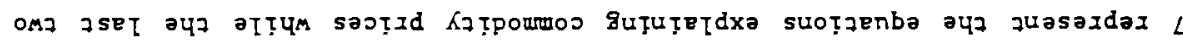

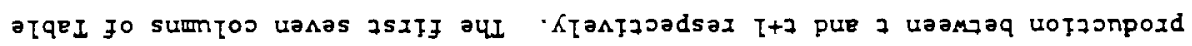

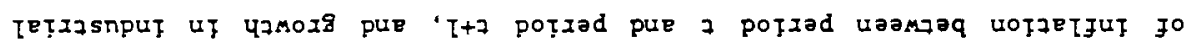

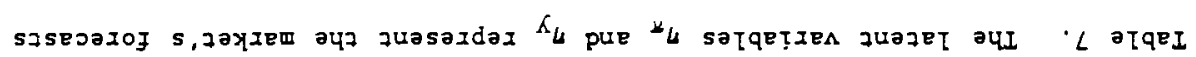

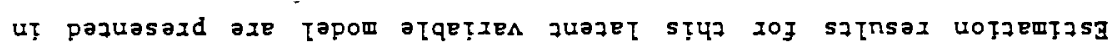

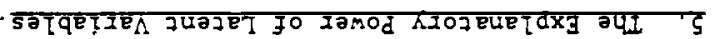

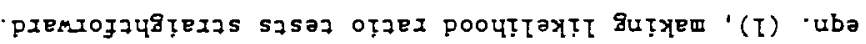

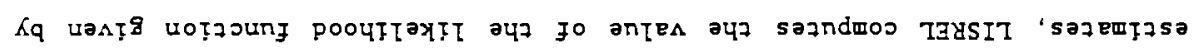

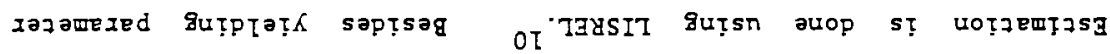
$6^{\cdot z \text { Indzno pue uoțzeTfuT }}$

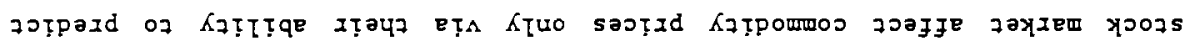

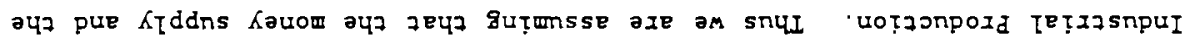
jo xapuI ay jo yzmoxg jo azeI s,forgad axau pue votzetgut s,potzad

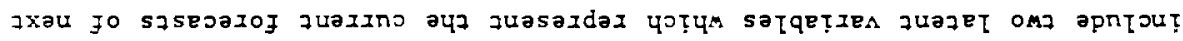

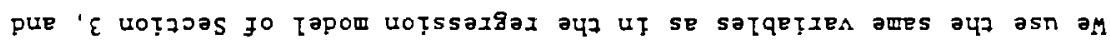

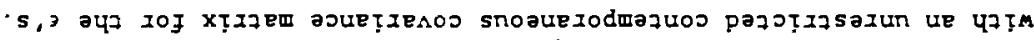

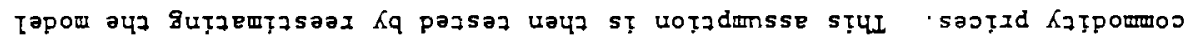

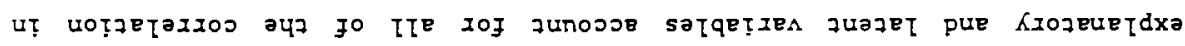

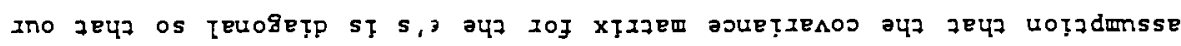

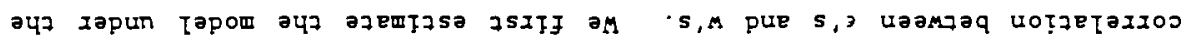


After estimating the model with the constraint that the covariance matrix of the $\epsilon^{\prime} s$ is diagonal, we reestimate it without that constraint. Even this less constrained model now incorporates some constraints since we still assume that the v's and w's are uncorrelated with the $\epsilon^{\prime} s$ and that the z's affect prices only through the latent variables. We test these secondary restrictions by constructing a likelihood ratio statistic which compares our less contrained nodel with an unconstrained alternative. This statistic is distributed as $x^{2}(25)$ when the restrictions are valid. 11 We obtain a value of 35.5 , which is insignificant at the 5 percent level.

Having estimated both the restricted and less restricted models, we do a likelihood ratio test on the restrictions implied by a diagonal covariance matrix. The test statistic is 49.7 This statistic, which measures the extent to which the 21 restrictions on the off diagonal elements are violated, is smaller than the value of 88.6 that we obtained in the OLS case, but is still significant at the lo level. Thus, even after including latent variables there is still excess co-movement of comodity prices.

We estimated several variations of this basic model, Including two models with only one latent variable. The first has a latent variable for the market forecast of future inflation, and the second has a latent variable for the market forecast of growth in industrial production. The statistics of the hypothesis of no excess co-movement, which again are distribued as $x^{2}(21)$ under the null, are 48.2 and 57.0 for the first and second models respectively. Thus, forecasted inflation has more to do with Joint movements of commodity prices than does forecasted production growth. Also note that the evidence against the hypothesis of no excess comovement is slightly weaker when we include only the latent variable for inflation than when we include both. This means that simply adding latent 


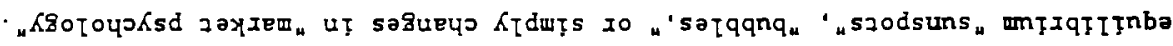

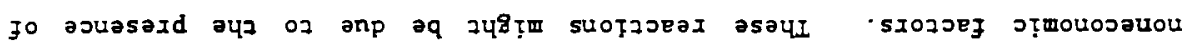

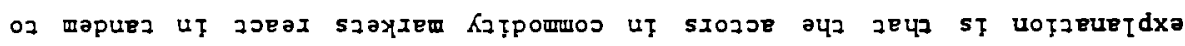

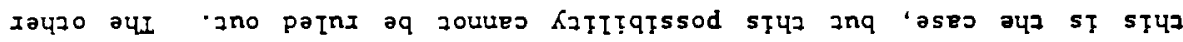

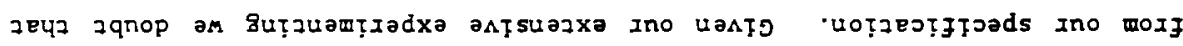

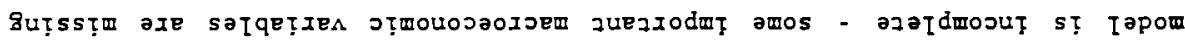

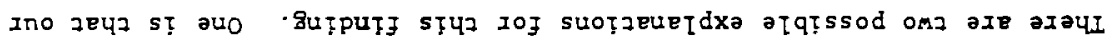
- satqețen zuazei pastasqoun lo paseq osje aje jo

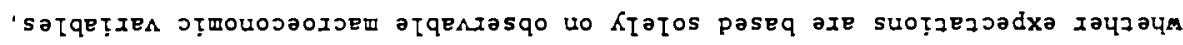

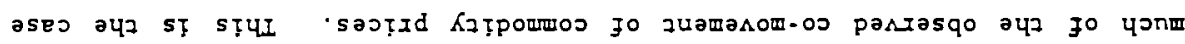
Ioj zunosoe zou op satqejter fo sputy asayz zeyz umoys aney aM satqețen

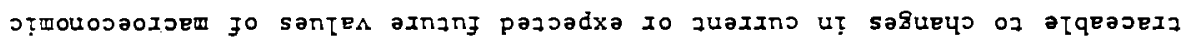

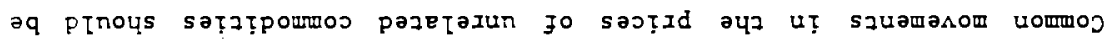

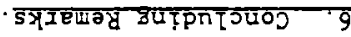

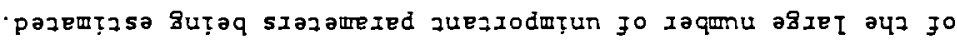

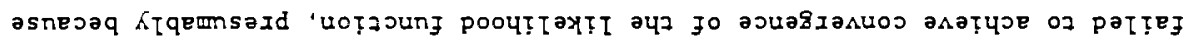

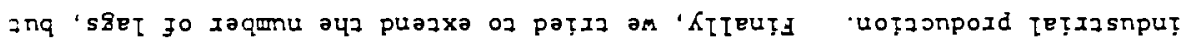

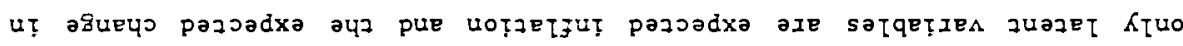

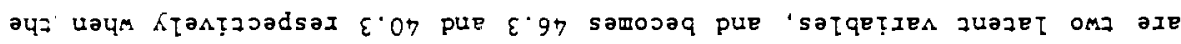

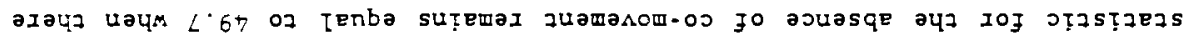

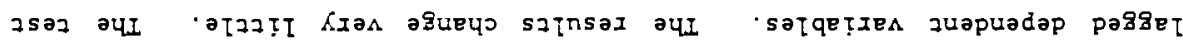

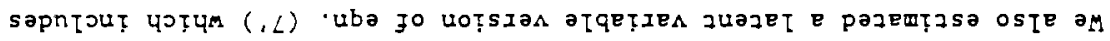

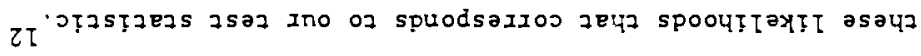

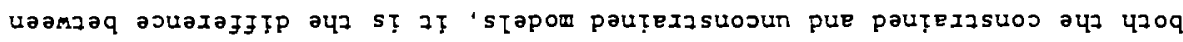

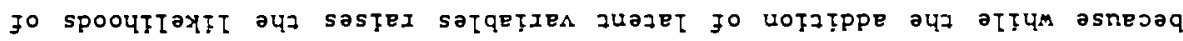

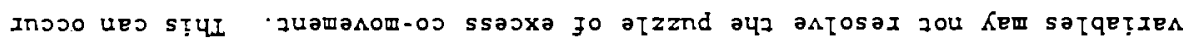


In any case, this would represent a rejection of the standard competitive model of comodity price formation in the presence of storage.

There are also alternative explanations for the dependence of our results on the length of the holding period. We have shown that as we increase the interval over which price changes are measured from a month to a quarter or a year, the amount of price movements which can be attributed to macroeconomic variables rises while the amount of unexplained co-movement rises as we 11 .

One possible reason for this finding is that there is considerable high-frequency mean-reverting noise in individual commodity prices. As a result neither macroeconomic variables nor prices of other commodities explain a large fraction of individual monthly price changes.

A second possibility is consistent with the view that we have excluded relevant macroeconomic variables from our model. Suppose that changes in macro variables affect commodity price slowly. For example, an unusual monthly change in inflation might have to persist for some time before it affects perceptions about the future. Such slow effects are consistent with our finding that macro variables explain more of the movements in comodity prices over longer holding periods. Then any excluded macro variable will also explain more of the price movements for longer holding periods. This means that its exclusion increases the unexplained co-movement as the holding period is increased.

A third possibility is that common price movements are the result of liquidity effects. The fall in the price of one commodity lowers the price of others only because it impoverishes speculators who are long in several commodities at once. These liquidity effects should be larger the larger is the change in any single commodity's price. The variance of price changes 


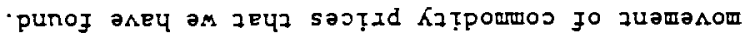

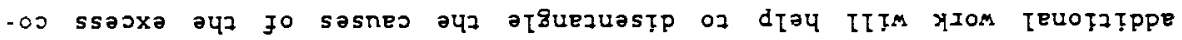

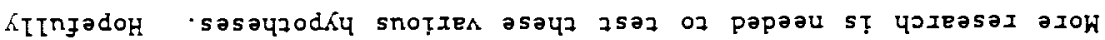

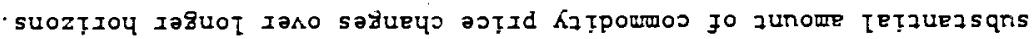

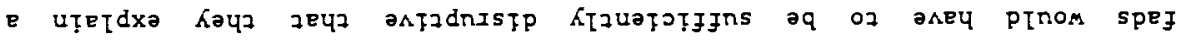

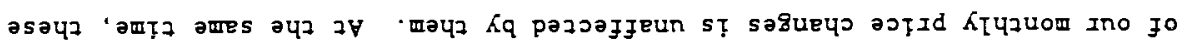

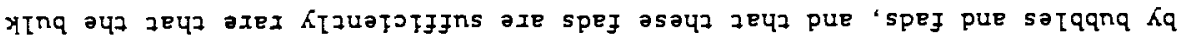

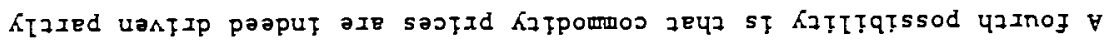

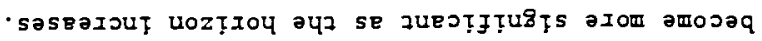

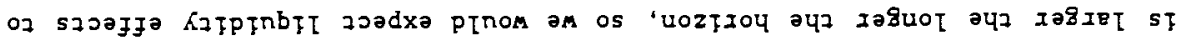




\section{APPENDIX A}

Here we derive eqn. (7) from eqns. (2) through (6) and a linearization. In particular we use a linearization of (4) analogous to that employed by Campbell and Shiller (1986) to obtain a linear expression for the logarithm of price. Ignoring commodity specific subscripts, eq̣. (4) becomes:

$$
1+I_{t}+\epsilon_{t}-R_{t}=\left[P_{t+1}-C_{t}\right] / P_{t}-\left(P_{t+1} / C_{t+1}\right)\left(C_{t+1} / C_{t}\right)\left(C_{t} / P_{t}\right)-C_{t} / P_{t}
$$

where $R_{C}$ is the ex post return and $\epsilon_{t}$ can be thought of as the unexpected return. The logaritim of $R_{t}$ is approximated at the point where $C_{t} / P_{t}$ equals a constant $h$ and $C_{t+1} / C_{t}$ equals a constants. Then

$$
\log \left(R_{t}\right)=s-h+\left[\left(p_{t+1}-P_{t}-s\right) s \cdot\left(c_{t}-P_{t}-h\right) h\right] /(s-h)
$$

where $c=\log C$ and $P=\log P$. Therefore, linearizing the $\log$ of $\left(1+\delta_{\tau}+\epsilon_{\tau}\right)$, eqn. (4) can be approximated as:

$$
I_{t} \approx E_{t} \delta P_{t+1}-P_{t}-2 h+(1-\delta) c_{t}
$$

where $\delta-s /(s-h)$. Using (5), we now have:

$$
E_{t} \delta P_{i, t+1}-P_{i, t}-2 h+(1-\delta)\left[n_{i, t}+\gamma_{i} I_{i, t}\right]-I_{t} \approx 0
$$

To simplify notation, we now subsume variations in the discount rate $I$ in $n_{i, t}$ (so that $n_{i, t}$ corresponds to $\left[n_{i, t}-r_{t} /(1-\delta)\right]$ ).

To complete the model we also require a transversality condition:

$$
\lim _{T \rightarrow \infty} \delta^{(I-\tau)} E_{t} I_{i, T}=0
$$

Combining (2), ( 3 ), and (A2) gives a difference equation for $I_{i, t}$ :

$$
E_{t} I_{i, t+1}-\frac{\left(1+\delta+b_{i} \gamma_{i}\right)}{\delta} I_{i, t}+\frac{1}{\delta} I_{i, t-1}-a_{i, t+1}-\frac{1}{\delta} a_{i, t}-\frac{1}{\delta} b_{i} n_{i, t}
$$

By factoring eqn. (A3), one can show that its non-explosive solution is:

$$
I_{i, t}-k_{i} I_{i, t-1}+d_{i} E_{t} \sum_{j=0}^{\infty} d_{i}^{j}\left(a_{i, t+j}-\delta a_{i, t+j+1}+b_{i} n_{i, t+j}\right)
$$

where $k_{i}$ and $d_{i}$ are commodity-specific constants which lie between 0 and 1 and depend on $b_{i}, \gamma_{i}$, and $\delta$. Eqn. (A4) describes the change in inventories in terms of current and expected future values of $a_{i, t}$ and $c_{i, t}$. To see 
$\cdot(, L)$ uba uf se atqejzen zuapuadap pagset e gutompozzuT

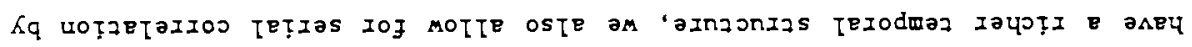

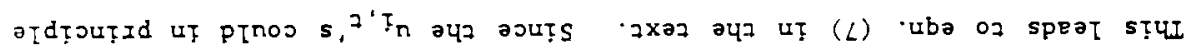

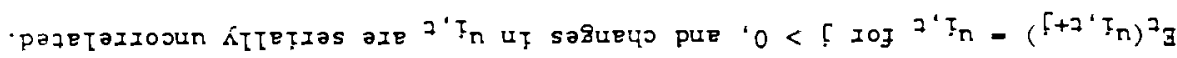

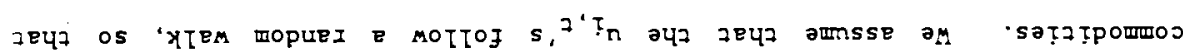

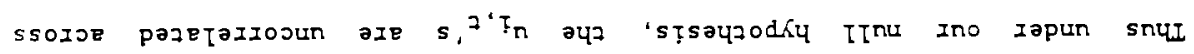

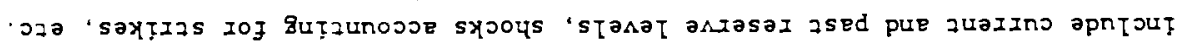

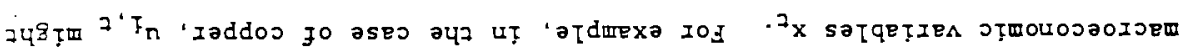

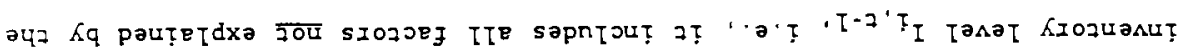

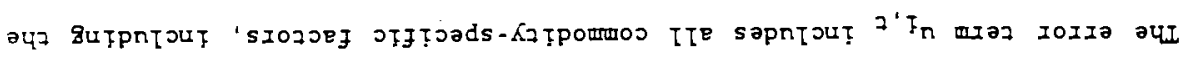

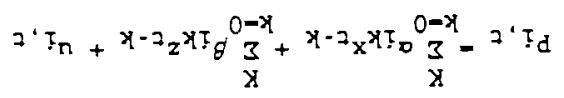

$$
\begin{aligned}
& \text { : uṭezqo am ((9) u० paseq axe }
\end{aligned}
$$

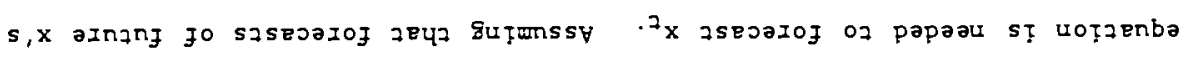

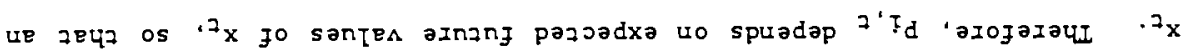
jo santen pasiet pue zuazino uo puadap yzoq $z^{\prime} T_{0}$ pue 2 'T zeyz tTejay

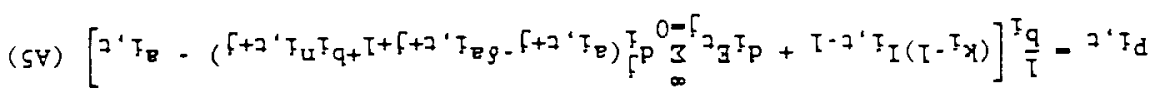

$$
\begin{aligned}
& :(\neg \forall) \text { pue }(\varepsilon) '(Z) \text { 'suba aufqmos } 17^{\prime} I_{U} \text { pue }
\end{aligned}
$$

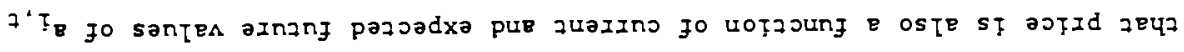




\section{APPENDIX B}

Monthly cash price data for January 1960 through December 1985 eame from the following sources:

Cocoa: Through January 1985, Bureau of Labor Statistics, "Spot Cocoa Bean Prices in New York." February 1985 onwards, average dally cash price quoted in Chicago for Accra delivery.

Copper: Commodity Yearbook, "Producers' Prices of Electrolytic (Wirebar) Copper, Deilvered U.S. Destinations," American Metal Market. Data are monthly averages of daily wholesaie delivered cash prices.

Cotton: Commodity Yearbook, "Average Spot Price of U.S. Cotton, 1-1/16 inches, Strict Low Middling at Designated Markets, Agricultural Marketing Service, USDA.

Crude Oil: Platts Oil Price Handbook and Oilmanac, Annual Editions, "Average Wholesale Price of Crude Petroleum as Collected by the Independent Petroleum Association of America."

Gold: Handy and Harmon cash price. A monthly average of daily spot prices.

Lumber: Bureau of Labor Statistics, "Aggregate Price Index for Lumber and Primary Lumber Products."

Whear: Comodity Yearbook, "Average Price of Number I Hard Winter wheat, at Kansas City," Agricultural Marketing Service, USDA. 


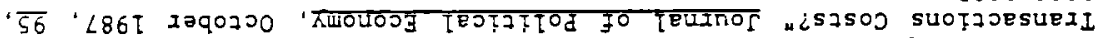

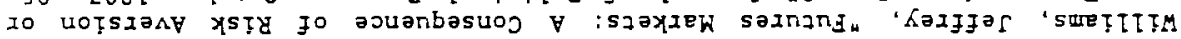

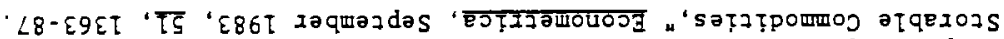

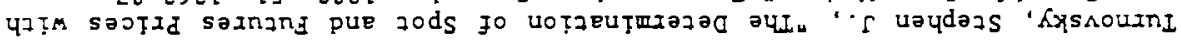

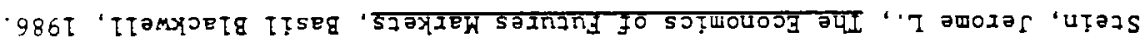

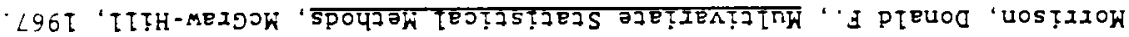

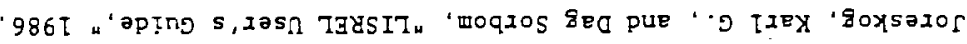

$$
\subseteq T \cdot \tau \cdot \overline{E T} \cdot \tau L 6 T
$$

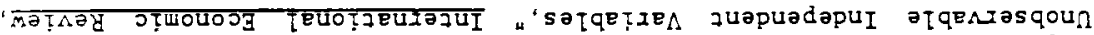

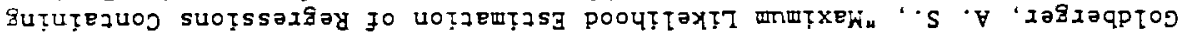

$$
96 \cdot T L \cdot \overline{7 T}
$$

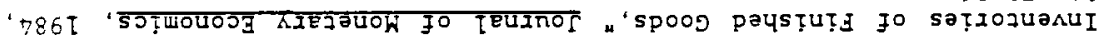

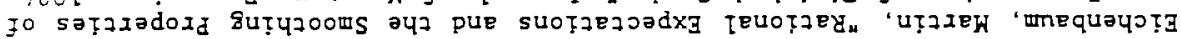

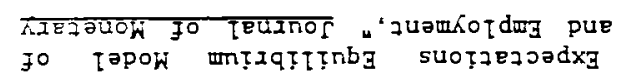

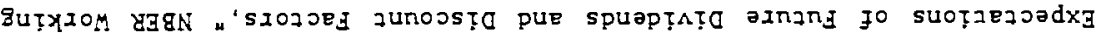

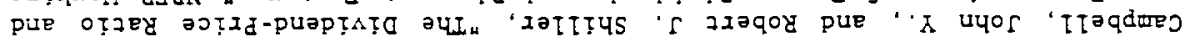

'786T 'pUETTOH-YבION 'II 'TOA '

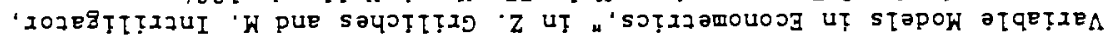

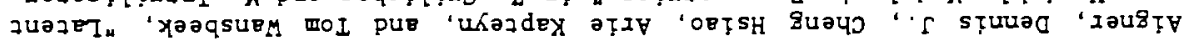

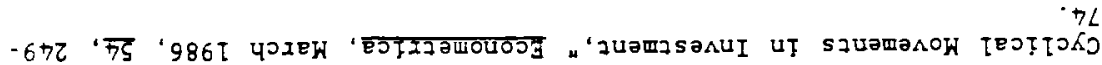

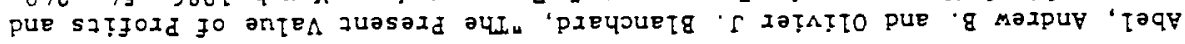

\section{SIJNerexts}




\section{EOOTNOTES}

1. Limited experimentation with other sets of comodities, including replacing gold with platinum, had little effect on our results.

2. This model is similar in structure to the finished goods inventory model of Eichenbaum (1983). It is also simllar to the comodity price models of Stein (1986) and Turnovsky (1983), but more general in that they assume i.i.d. shocks, and we allow for a more general error structure.

3. For an explicit model of convenience yield that illustrates some of these general dependencies, see Williams (1987).

4. The interest rate is in level rather than first-differenced form. This is consistent with the first difference of the interest race affecting the rate of change of comodity prices. We include the level of interest rates because it may well be a good predictor of future inflation and because equation (4) suggests that levels of interest rates may help predict individual comodity price changes.

5. The $\mathrm{R}^{2}$ 's for the regressions that use only macroeconomic explanatory variables increase substantially as we lengthen the holding period, which partly explains the larger raw correlations of commodity price changes for longer holding periods shown in Iables 1 to 3.

6. We focus on the 1960:4 to 1985:11 period because of the major change in U.S. government intervention in the cotton market that occured in 1986.

7. We also considered the weather as an explanator that could affect all comodities, and included U.S. data on heating degree days, cooling degree days, temperature, and precipitation. This had virtually no effect on our results; the resulting $x^{2}$ was 87.7 .

8. See Goldberger (1972) and Algner et. al. (1984).

9. In some sense this is more restrictive than in the earlier regression model because there the money supply and the stock market were potential predictors of all other $x$ 's as well.

10. The 1nput 15 the correlation matrix $\Omega$ of all the variables of interest. Thus this matrix includes the correlations among the changes in commodity prices, the $x^{\prime} s$, the $z^{\prime} s$ and the future values of inflation and production growth. See Joreskog and Sorbom (1986).

11. Ignoring the $x^{\prime} s$, the model has 7 prices, 2 future macroeconomic variables, and 4 instruments, for a total of 78 covarlances. The test statistic for the less restricted model has 25 degrees of freedom because that model includes 53 free parameters: 21 covariances of the $\epsilon_{1}^{\prime} s, 14 \mathrm{~g}_{1}^{\prime} \mathrm{s}$ in eqn. (11), $8 \phi^{\prime} \mathrm{s}$ in eqn. (9), 3 elements of the covariance matrix for eqn. (9), I covariance of the $w_{t}^{\prime} s$ in (12), and the 6 free covariances of our instruments. 


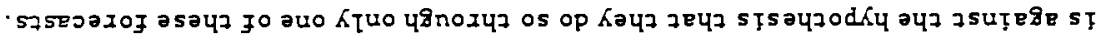

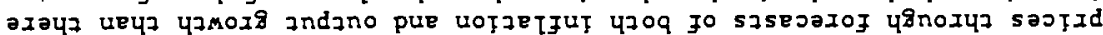

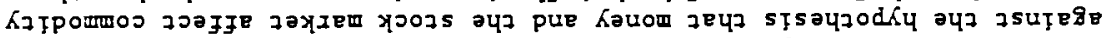

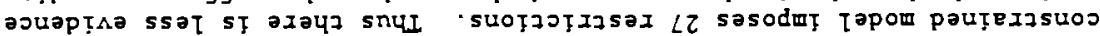

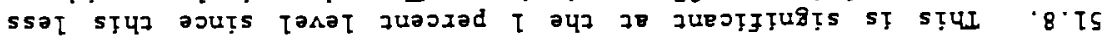

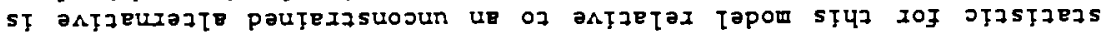

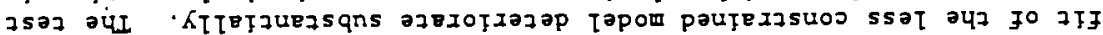

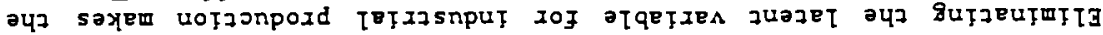




\section{TABIE 1}

Correlations of Monthly Log Changes in Commodity Prices

WHEAT COTTON COPPER GOLD CRUDE LUMBER COCOA

$\begin{array}{llllllll}\text { WHEAT } & 1.000 & & & & & & \\ \text { COTTON } & 0.253 & 1.000 & & & & & \\ \text { COPPER } & 0.051 & 0.152 & 1.000 & & & & \\ \text { GOLD } & -0.020 & 0.045 & 0.322 & 1.000 & & \\ \text { CRUDE } & 0.103 & 0.098 & 0.032 & 0.245 & 1.000 & \\ \text { LUMBER } & -0.059 & 0.125 & 0.113 & 0.126 & -0.085 & 1.000 & \\ \text { COCOA } & -0.014 & 0.043 & 0.052 & 0.135 & 0.013 & 0.122 & 1.000 \\ & & & \chi^{2}(21)-114.6 & . & & \end{array}$




$$
\varsigma \cdot \varepsilon \varsigma-(\tau \tau) \tau^{x}
$$

\begin{tabular}{|c|c|c|c|c|c|c|c|}
\hline \multirow[t]{7}{*}{$000^{\circ} \mathrm{I}$} & ZOE 0 & $\varepsilon \gg 0^{\circ} 0^{-}$ & $\rightarrow \tau \tau \cdot 0$ & $8 z \tau^{\prime} 0$ & $580^{\circ} 0$ & $0 S 0^{\circ} 0$ & *0000 \\
\hline & $000^{\circ} \mathrm{I}$ & $960^{\circ} 0^{-}$ & $\tau \tau \tau^{\circ} 0$ & ZSI'0 & $\varsigma 2 Z \cdot 0$ & $\varepsilon z 0^{\circ} \circ$ & ¿قghnI \\
\hline & & $000^{\circ} \tau$ & $6 \tau \nabla^{\circ} 0$ & $820^{\circ} 0$ & $\varepsilon 90^{\circ} 0$ & $z+\tau \cdot 0$ & Jango \\
\hline & & & $000^{\circ} \mathrm{I}$ & $\tau 6 \varepsilon^{\circ} 0$ & $8 \varepsilon \tau^{\prime} 0$ & $9 \varepsilon \tau^{\circ} 0$ & T100 \\
\hline & & & & $000^{\circ} \mathrm{I}$ & $\nabla \varsigma Z^{\prime} 0$ & $\varsigma 60^{\circ} 0$ & yaddOD \\
\hline & & & & & $000^{\circ} \tau$ & $00 \varepsilon^{\prime} 0$ & NOIIOO \\
\hline & & & & & & $000^{\circ} \tau$ & IVIHM \\
\hline
\end{tabular}

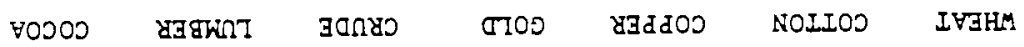




\section{TABLE 3}

Correlations of Nonoverlapping Annual Log Changes in Commodity Prices

WHEAT COTTON COPPER GOLD CRUDE LUMBER COCOA

$\begin{array}{llllllll}\text { WHEAT } & 1.000 & & & & & & \\ \text { COTTON } & 0.504 & 1.000 & & & & & \\ \text { COPPER } & 0.430 & 0.352 & 1.000 & & & & \\ \text { GOLD } & 0.606 & 0.462 & 0.521 & 1.000 & & & \\ \text { CRUDE } & 0.354 & 0.246 & 0.325 & 0.548 & 1.000 & \\ \text { LUMBER } & 0.313 & 0.458 & 0.099 & 0.275 & -0.176 & 1.000 & \\ \text { COCOA } & 0.272 & 0.289 & 0.241 & 0.233 & -0.030 & 0.582 & 1.000 \\ & & & x^{2}(21)-56.3 & & & \end{array}$




\begin{tabular}{|c|c|c|c|c|c|c|c|}
\hline$\angle 8^{\circ} \mathrm{T}$ & $O I \cdot \tau$ & $I S^{\cdot} \mathrm{I}$ & $07^{\circ} \mathrm{I}$ & $87^{\circ} \mathrm{I}$ & $\tau * \tau$ & $\neg \varepsilon \cdot \tau$ & $M \sigma$ \\
\hline$\angle 0^{\circ}$ & $8 \mathrm{I}^{\circ}$ & II & $7 z^{\circ}$ & $60^{\circ}$ & $50^{\circ}$ & $90^{\circ}$ & $2^{8}$ \\
\hline $\begin{array}{l}\left(5^{\circ} 0^{-}\right) \\
620^{\circ}-\end{array}$ & $\begin{array}{l}\left(7^{\circ} \mathrm{I}\right) \\
280^{\circ}\end{array}$ & $\begin{array}{l}\left(\zeta^{\cdot} \tau^{-}\right) \\
\zeta \nabla \tau^{\circ}\end{array}$ & $\begin{array}{l}\left(L^{\circ} T^{-}\right) \\
\angle 60^{\circ}-\end{array}$ & $\begin{array}{l}\left(6^{\circ} I^{-}\right) \\
6 I^{\circ}-\end{array}$ & $\begin{array}{l}\left(\angle O^{\circ}\right) \\
\eta † 0^{\circ} \cdot\end{array}$ & $\begin{array}{l}\left(\varepsilon^{\circ} \tau^{-}\right) \\
780^{\circ}-\end{array}$ & $\left(I^{-}\right) \mathrm{S}$ \\
\hline $\begin{array}{l}\left(\varepsilon^{\circ} \tau\right) \\
180^{\circ}\end{array}$ & $\begin{array}{l}\left(8^{\circ} 0\right) \\
\varepsilon 5^{\circ}\end{array}$ & $\begin{array}{l}\left.\left(6^{\circ}\right)^{\prime}\right) \\
\text { III }\end{array}$ & $\begin{array}{l}\left(\eta^{\circ} I\right) \\
\angle \angle 0^{\circ}\end{array}$ & $\begin{array}{l}\left(8^{\circ} 0\right) \\
050^{\circ}\end{array}$ & $\begin{array}{l}\left(S^{\circ} \tau\right) \\
760^{\circ}\end{array}$ & $\begin{array}{c}\left(50^{\circ} 0^{-}\right) \\
\varepsilon 00^{\circ}-\end{array}$ & $\mathbf{S}$ \\
\hline $\begin{array}{l}\left(\varepsilon^{\circ} 0\right) \\
8\left[0^{\circ}\right.\end{array}$ & $\begin{array}{l}\left(0^{\circ} \tau\right) \\
790^{\circ}\end{array}$ & $\begin{array}{l}\left(0^{\circ} \mathrm{I}\right) \\
{\left[90^{\circ}\right.}\end{array}$ & $\begin{array}{l}\left(8^{\circ} Z\right) \\
S \angle I^{\circ}\end{array}$ & $\begin{array}{l}\left(0^{\circ} I^{-}\right) \\
\varepsilon 90^{\circ}-\end{array}$ & $\begin{array}{l}\left(\varepsilon^{\circ} \tau\right) \\
880^{\circ}\end{array}$ & $\begin{array}{l}\left(L^{\circ} 0^{-}\right) \\
\varsigma \neq 0^{\circ}-\end{array}$ & $(\tau \cdot) \mathrm{W}$ \\
\hline $\begin{array}{c}(70) \\
920^{\circ}\end{array}$ & $\begin{array}{c}\left(0^{\circ} \varepsilon\right) \\
\tau 8 I^{\circ}\end{array}$ & $\begin{array}{c}\left(200^{\circ} 0\right) \\
\text { I00 }\end{array}$ & $\begin{array}{c}(\tau \cdot \tau) \\
0 \tau \tau^{\circ}\end{array}$ & $\begin{array}{c}\left(z^{*} \varepsilon\right) \\
\angle O Z^{\circ}\end{array}$ & $\begin{array}{c}\left(9^{\circ} 0^{-}\right) \\
6 \varepsilon 0^{\circ}-\end{array}$ & $\begin{array}{l}\left(0^{\circ} 2\right) \\
\varepsilon \varepsilon \tau^{\circ}\end{array}$ & W \\
\hline $\begin{array}{l}\left(8^{\circ} 0\right) \\
{\left[50^{\circ}\right.}\end{array}$ & $\begin{array}{l}(L \cdot \tau) \\
8 \varsigma I^{\cdot}\end{array}$ & $\begin{array}{c}\left(9^{\circ} 0\right) \\
\varepsilon \varepsilon 0^{\circ}\end{array}$ & $\begin{array}{l}\left(\mathrm{I}^{\cdot} \mathrm{I}^{-}\right) \\
790^{\circ}-\end{array}$ & $\begin{array}{l}\left(\tau^{\circ} \tau\right) \\
\angle 90^{\circ}\end{array}$ & $\begin{array}{c}\left(T^{\circ} \tau\right) \\
0 \angle 0^{\circ}\end{array}$ & $\begin{array}{l}\left(\varepsilon^{\circ} 0^{-}\right) \\
6 \tau 0^{\circ}\end{array}$ & $\left(I^{-}\right) \mathbf{J}$ \\
\hline $\begin{array}{c}\left(I^{\circ} I\right) \\
890^{\circ}\end{array}$ & $\begin{array}{l}\left(0^{\circ} 0^{-}\right) \\
200^{\circ}-\end{array}$ & $\begin{array}{l}\left(\eta \tau^{\circ}\right) \\
9 \eta I^{\circ}=\end{array}$ & $\begin{array}{c}(\varsigma \cdot \varsigma) \\
\varsigma \tau \varepsilon\end{array}$ & $\begin{array}{c}(\tau \cdot \tau) \\
I+\tau\end{array}$ & $\begin{array}{l}\left(Z^{\circ} \mathrm{I}^{-}\right) \\
\angle \angle 0^{\circ}-\end{array}$ & $\begin{array}{c}\left(6^{\circ} 0^{-}\right) \\
950^{\circ} .\end{array}$ & $\mathbf{I}$ \\
\hline $\begin{array}{l}\left(8^{\circ} 0^{-}\right) \\
\varepsilon O \varepsilon^{\circ}-\end{array}$ & $\begin{array}{l}\left(S^{\circ} I^{-}\right) \\
805^{\circ}-\end{array}$ & $\begin{array}{l}\left(6^{\circ} 0\right) \\
862^{\circ}\end{array}$ & $\begin{array}{l}\left(8^{\circ} 0^{-}\right) \\
892^{\circ}\end{array}$ & $\begin{array}{l}\left(\eta^{\circ} \tau^{-}\right) \\
587^{\circ}-\end{array}$ & $\begin{array}{l}\left(L^{\circ} 0^{-}\right) \\
7 \varsigma^{\circ} Z^{\circ}\end{array}$ & $\begin{array}{l}\left(z \cdot 0^{-}\right) \\
9 L 0^{-}\end{array}$ & $(I-) \mathrm{d}$ \\
\hline $\begin{array}{c}(\angle \cdot 0) \\
79 Z^{\circ}\end{array}$ & $\begin{array}{c}\left(6^{\circ} 0\right) \\
\tau Z \varepsilon^{\circ}\end{array}$ & $\begin{array}{l}\left(\varepsilon^{\circ} T-\right) \\
997^{\circ}-\end{array}$ & $\begin{array}{c}\left(\varepsilon 0^{\circ} 0^{-}\right) \\
600^{\circ}-\end{array}$ & $\begin{array}{l}\left(I^{\circ} \mathrm{I}\right) \\
\mathrm{IZ}^{\circ}\end{array}$ & $\begin{array}{c}(7 \circ 0) \\
59 I^{\circ}\end{array}$ & $\begin{array}{r}\left(20^{\circ} 0^{-}\right) \\
\angle 00^{\circ}-\end{array}$ & $y$ \\
\hline $\begin{array}{l}\left(L^{\circ} I^{\prime}\right) \\
60 T^{\circ}\end{array}$ & $\begin{array}{l}\left(I^{\circ} I\right) \\
990^{\circ}\end{array}$ & $\begin{array}{l}\left(6^{\circ} 0^{-}\right) \\
\tau 50^{\circ}-\end{array}$ & $\begin{array}{l}\left(\tau^{\circ} I-\right) \\
0 \angle 0^{\circ}-\end{array}$ & $\begin{array}{l}\left(6^{\circ} 0\right) \\
550^{\circ}\end{array}$ & $\begin{array}{l}(\angle \circ 0) \\
S \neq 0^{\circ}\end{array}$ & $\begin{array}{l}\left(\varepsilon^{\circ} \tau\right) \\
280^{\circ}\end{array}$ & $\left(I^{-}\right) X$ \\
\hline $\begin{array}{l}\left(6^{\circ} I\right) \\
\rightarrow \tau I\end{array}$ & $\begin{array}{c}(9 \cdot 0) \\
0 \neq 0^{\circ}\end{array}$ & $\begin{array}{c}\left(7^{\circ} \tau^{*}\right) \\
880^{\circ}-\end{array}$ & $\begin{array}{l}\left(0^{\circ} \mathrm{I}^{-}\right) \\
850^{\circ}-\end{array}$ & $\begin{array}{l}\left(7^{\circ} 0\right) \\
\angle 20^{\circ}\end{array}$ & $\begin{array}{c}\left(Z^{\circ} I\right) \\
080^{\circ}\end{array}$ & $\begin{array}{r}\left(10^{\circ} 0^{\circ}\right) \\
\text { I00 }\end{array}$ & $\pi$ \\
\hline $\begin{array}{l}\left(\eta^{\circ} I^{\prime}\right) \\
O Z \tau^{\circ}\end{array}$ & $\begin{array}{c}\left(6^{\circ} \mathrm{I}\right) \\
5 \varsigma \mathrm{I}^{\circ}\end{array}$ & $\begin{array}{c}(\tau \cdot \tau) \\
0<I^{\circ}\end{array}$ & $\begin{array}{c}\left(\sigma^{\circ} \tau\right) \\
\varepsilon \circ \tau^{\circ}\end{array}$ & $\begin{array}{c}\left(\mathrm{I}^{\circ} \mathrm{O}^{-}\right) \\
600^{\circ}-\end{array}$ & $\begin{array}{l}\left(\varepsilon^{\cdot} \tau\right) \\
70 \tau^{\prime}\end{array}$ & $\begin{array}{l}\left(8^{\circ} \mathrm{I}^{-}\right) \\
\mathrm{Ig}^{\circ}-\end{array}$ & $\left(I^{-}\right)^{4}$ \\
\hline $\begin{array}{l}\left(L^{\circ} O^{-}\right) \\
790^{\circ}-\end{array}$ & $\begin{array}{l}\left(0^{\circ} \mathrm{I}^{-}\right) \\
6 \angle 0^{\circ}-\end{array}$ & $\begin{array}{c}\left.(\tau)^{\cdot}\right) \\
\varepsilon \varepsilon \varepsilon\end{array}$ & $\begin{array}{c}\left(L^{\cdot} \tau\right) \\
\zeta \varepsilon \tau^{\circ}\end{array}$ & $\begin{array}{c}\left(8^{\circ} 0\right) \\
0<0^{\circ}\end{array}$ & $\begin{array}{l}\left(6^{\circ} 0^{\circ}\right) \\
{\left[80^{\circ}-\right.}\end{array}$ & $\begin{array}{c}(\tau \cdot \varepsilon) \\
\varepsilon<\tau^{\circ}\end{array}$ & 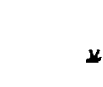 \\
\hline Yoว0ग & gaghn & zanyo & TIOS & yتddOD & NOIIOO & IУ्aHM & \\
\hline \multicolumn{8}{|c|}{ 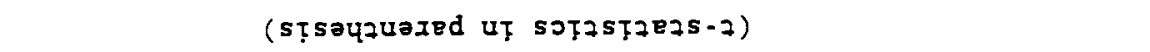 } \\
\hline & & $\overline{S L}$ & $\begin{array}{c}0 \text { T5Sasta } \\
7 \mathrm{~s} 18 \mathrm{~V}\end{array}$ & II 570 & & & \\
\hline
\end{tabular}




\section{TABLE 5 \\ $x^{2}$ Statistics for Group Exclusions \\ of the Explanatory Vartables}
(1) INF
$73.22^{\star \star}$
$127.29^{\star \star}$
(2) INDST
$29.48^{\star \star}$
$71.56^{\star}$
(3) TBILI
$29.32^{\star \star}$
$93.24^{\star \star}$
(4) $\mathrm{EXCH}$
$62.06^{\star \star}$
$166.41^{\star \star}$
(5) $\mathrm{MI}$
$36.29^{\star \star}$
$81.93^{\star \star}$
(6) STOCK
20.44
$101.05^{\star \star}$

Diagonal Correlation

Matrix:

$89.36^{\star \star}$

$99.44^{\star \star}$

* Significant at $5 \%$ level

** Significant at 18 level 


\begin{tabular}{|c|c|c|c|c|c|c|}
\hline $068^{\circ}$ & $2 \angle 8^{\circ}$ & $60 z^{\circ}$ & $6 S^{\circ}$ & $\varsigma 80^{\circ}$ & - $690^{\circ}$ & Y0000 \\
\hline $878^{\circ}$ & $\varepsilon \varsigma L^{\circ}$ & $86 Z^{\circ}$ & $6 \angle Z^{\circ}$ & $\angle 8 \mathrm{I}^{\circ}$ & $\angle L T^{\circ}$ & पyaghoา \\
\hline $7 \angle 6^{\circ}$ & $776^{\circ}$ & $287^{\circ}$ & 207 & โ9: & $\operatorname{IIZ}$. & zaneo \\
\hline $096^{\circ}$ & $806^{\circ}$ & $86 \varepsilon^{\circ}$ & $\varepsilon<\varepsilon^{\circ}$ & $\varepsilon \varepsilon \varepsilon^{\circ}$ & カカ2 & ब]०D \\
\hline $906^{\circ}$ & TOL & 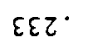 & $6 \angle I^{\circ}$ & I8 $I^{\circ}$ & $060^{\circ}$ & yaddos \\
\hline$\angle 88^{\circ}$ & LOT. & $\angle 9 \varepsilon^{\circ}$ & $8 \angle Z^{\circ}$ & $\nabla \varsigma \tau^{\circ}$ & $\varepsilon \varsigma 0^{\circ}$ & NOIIOS \\
\hline $688^{\circ}$ & $\angle L S^{\circ}$ & $\angle \varepsilon Z^{\circ}$ & $9 \varepsilon \tau^{\circ}$ & $\varsigma \varepsilon \tau^{\circ}$ & $950^{\circ}$ & $I \forall E H M$ \\
\hline$\overline{\text { पराप }}$ & $\overline{7 n O 4 ? T M}$ & $\overline{47 ? \square}$ & 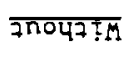 & $\overline{47 ! M}$ & $\overline{7 n o y ? T M}$ & 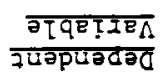 \\
\hline & $\overline{\mathrm{LWV}}$ & $\overline{X T R}$ & $\overline{\text { Lप्रषणठ }}$ & $\overline{\mathrm{X} T \mathrm{H}}$ & NOW & d guțpโоH \\
\hline
\end{tabular}

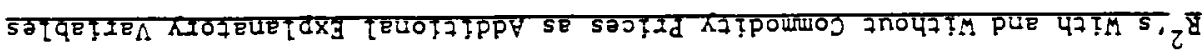
उद्वVI 


\section{TABLE 7 \\ Latent Variable Model}

WHEAT COTTON COPPER GOLD CRUDE LUMBER COCOA $\eta_{\pi} \ldots \eta_{\mathrm{y}}$

\begin{tabular}{|c|c|c|c|c|c|c|c|c|c|}
\hline$\eta_{\pi}$ & $\begin{array}{l}1.334 \\
(1.8)\end{array}$ & $\begin{array}{l}1.483 \\
(1.9)\end{array}$ & $\begin{array}{l}2.037 \\
(2.1)\end{array}$ & $\begin{array}{l}1.876 \\
(2.1)\end{array}$ & $\begin{array}{l}2.247 \\
(2.3)\end{array}$ & $\begin{array}{r}-1.648 \\
(-1.2)\end{array}$ & $\begin{array}{l}0.563 \\
(0.9)\end{array}$ & & \\
\hline$\eta_{y}$ & $\begin{array}{l}-0.262 \\
(-0.6)\end{array}$ & $\begin{array}{l}0.249 \\
(0.5)\end{array}$ & $\begin{array}{l}0.611 \\
(1.1)\end{array}$ & $\begin{array}{l}0.703 \\
(1.3)\end{array}$ & $\begin{array}{l}-0.324 \\
(-0.6)\end{array}$ & $\begin{array}{l}2.290 \\
(2.4)\end{array}$ & $\begin{array}{l}0.345 \\
(0.9)\end{array}$ & & \\
\hline$\pi$ & $\begin{array}{l}-0.308 \\
(-0.9)\end{array}$ & $\begin{array}{l}-0.698 \\
(-2.0)\end{array}$ & $\begin{array}{l}-0.773 \\
(-1.8)\end{array}$ & $\begin{array}{l}-0.641 \\
(-1.5)\end{array}$ & $\begin{array}{l}-0.636 \\
(-1.4)\end{array}$ & $\begin{array}{l}0.689 \\
(1.1)\end{array}$ & $\begin{array}{l}-0.294 \\
(-1.0)\end{array}$ & $\begin{array}{l}0.425 \\
(7.9)\end{array}$ & $\begin{array}{l}-0.033 \\
(-0.4)\end{array}$ \\
\hline$\pi(-1)$ & $\begin{array}{l}-0.577 \\
(-2.0)\end{array}$ & $\begin{array}{l}-0.226 \\
(-0.7)\end{array}$ & $\begin{array}{l}-0.529 \\
(-1.5)\end{array}$ & $\begin{array}{l}-0.288 \\
(-0.8)\end{array}$ & $\begin{array}{l}-0.540 \\
(-1.5)\end{array}$ & $\begin{array}{l}0.892 \\
(1.7)\end{array}$ & $\begin{array}{l}0.014 \\
(0.1)\end{array}$ & $\begin{array}{l}0.298 \\
(5.5)\end{array}$ & $\begin{array}{l}-0.111 \\
(-1.5)\end{array}$ \\
\hline$Y$ & $\begin{array}{l}0.123 \\
(0.7)\end{array}$ & $\begin{array}{l}0.046 \\
(0.3)\end{array}$ & $\begin{array}{c}-0.110 \\
(-0.5)\end{array}$ & $\begin{array}{l}-0.216 \\
(-1.0)\end{array}$ & $\begin{array}{l}0.087 \\
(0.4)\end{array}$ & $\begin{array}{r}-0.699 \\
(-2.0)\end{array}$ & $\begin{array}{l}0.034 \\
(0.2)\end{array}$ & $\begin{array}{l}-0.031 \\
(-0.8)\end{array}$ & $\begin{array}{l}0.315 \\
(5.6)\end{array}$ \\
\hline$Y(-1)$ & $\begin{array}{l}0.059 \\
(0.6)\end{array}$ & $\begin{array}{l}-0.061 \\
(-0.6)\end{array}$ & $\begin{array}{l}-0.095 \\
(-0.8)\end{array}$ & $\begin{array}{l}-0.238 \\
(-2.2)\end{array}$ & $\begin{array}{l}-0.125 \\
(-1.1)\end{array}$ & $\begin{array}{l}-0.094 \\
(-0.6)\end{array}$ & $\begin{array}{l}0.043 \\
(0.6)\end{array}$ & $\begin{array}{l}0.047 \\
(1.2)\end{array}$ & $\begin{array}{l}0.108 \\
(2.0)\end{array}$ \\
\hline $\mathbf{R}$ & $\begin{array}{l}-0.920 \\
(-1.6)\end{array}$ & $\begin{array}{r}-0.887 \\
(-1.4)\end{array}$ & $\begin{array}{l}-1.564 \\
(-2.1)\end{array}$ & $\begin{array}{r}-1.349 \\
(-1.9)\end{array}$ & $\begin{array}{l}-1.875 \\
(-2.5)\end{array}$ & $\begin{array}{l}0.476 \\
(0.5)\end{array}$ & $\begin{array}{l}-0.351 \\
(-0.7)\end{array}$ & $\begin{array}{l}0.697 \\
(3.4)\end{array}$ & $\begin{array}{l}0.428 \\
(1.5)\end{array}$ \\
\hline$R(-1)$ & $\begin{array}{l}0.651 \\
(1.2)\end{array}$ & $\begin{array}{l}0.618 \\
(1.2)\end{array}$ & $\begin{array}{l}1.268 \\
(1.9)\end{array}$ & $\begin{array}{l}0.911 \\
(1.4)\end{array}$ & $\begin{array}{l}1.378 \\
(2.1)\end{array}$ & $\begin{array}{l}-0.231 \\
(-0.3)\end{array}$ & $\begin{array}{l}0.265 \\
(0.6)\end{array}$ & $\begin{array}{l}-0.564 \\
(-2.8)\end{array}$ & $\begin{array}{l}-0.525 \\
(-1.9)\end{array}$ \\
\hline$E$ & $\begin{array}{l}-0.200 \\
(-1.8)\end{array}$ & $\begin{array}{l}-0.236 \\
(-2.0)\end{array}$ & $\begin{array}{l}-0.101 \\
(-0.7)\end{array}$ & $\begin{array}{l}0.131 \\
(1.0)\end{array}$ & $\begin{array}{l}-0.375 \\
(-2.6)\end{array}$ & $\begin{array}{l}0.151 \\
(0.8)\end{array}$ & $\begin{array}{l}0.005 \\
(0.1)\end{array}$ & $\begin{array}{l}0.106 \\
(2.7)\end{array}$ & $\begin{array}{l}0.012 \\
(0.3)\end{array}$ \\
\hline$E(-1)$ & $\begin{array}{l}0.125 \\
(1.1)\end{array}$ & $\begin{array}{l}0.199 \\
(1.7)\end{array}$ & $\begin{array}{l}0.256 \\
(1.8)\end{array}$ & $\begin{array}{l}0.103 \\
(0.8)\end{array}$ & $\begin{array}{l}0.248 \\
(1.7)\end{array}$ & $\begin{array}{l}-0.039 \\
(-0.2)\end{array}$ & $\begin{array}{l}0.097 \\
(1.0)\end{array}$ & $\begin{array}{l}-0.096 \\
(-2.5)\end{array}$ & $\begin{array}{l}0.017 \\
(0.3)\end{array}$ \\
\hline M & & & & & & & & $\begin{array}{l}0.034 \\
(1.5)\end{array}$ & $\begin{array}{l}0.104 \\
(2.9)\end{array}$ \\
\hline$M(-1)$ & & & & . & & & & $\begin{array}{l}0.021 \\
(1.1)\end{array}$ & $\begin{array}{l}0.048 \\
(1.6)\end{array}$ \\
\hline $\mathbf{s}$ & & & & & & & & $\begin{array}{l}0.035 \\
(2.0)\end{array}$ & $\begin{array}{l}0.034 \\
(1.2)\end{array}$ \\
\hline$S(-1)$ & & & & & & & & $\begin{array}{l}-0.054 \\
(-2.2)\end{array}$ & $\begin{array}{l}0.009 \\
(0.2)\end{array}$ \\
\hline
\end{tabular}

$\begin{array}{llllllllll}\mathbf{R}^{2} & 0.08 & 0.13 & 0.26 & 0.39 & 0.31 & 0.39 & 0.09 & 0.65 & 0.35\end{array}$ 